\title{
Da'wah Communication and Social Concern
}

\author{
Budi Suprapto ${ }^{1}$; Datin Hasmah Zainuddin ${ }^{2}$ \\ ${ }^{1}$ University of Muhammadiyah Malang Indonesia $;{ }^{2}$ University of Malaya Malaysia \\ ${ }^{1}$ Email: spbudhi@gmail.com
}

\begin{abstract}
The object of this study amounted to 414 people. They are participants in the da'wah (recitation) activity held by Persyarikatan Muhammadiyah and Qur'an Tafsir Council in the former residency of Surakarta, Central Java, Indonesia. The purpose of the study was to determine the influence of the dash on da'wah communication message toward the level of the behavior of social concern, as the main variable. As many factors are contributed in determining the effects of communication and the behavior of social concern, this study also involves 3 moderator variables, namely the activity of forwarding da'wah message interpersonally, reference groups, and the frequency of using mass media. Through Moderated Regression Analysis (MRA) test, the obtained results are that the three moderator variables serve to reinforce the influence of the dash on da'wah message toward social concern. Even based on the results of t-test, the role of each moderator variable is greater than the independent variable.
\end{abstract}

Keywords: the da'wah communication dash, forwarding message interpersonally, the use of mass media, reference groups, social concern.

\section{Introduction}

The disclosure from faith into good deeds in the midst of societal life is the essence of the precept in every religion. It means as thick and strong as a person's religious belief is, there is no benefit if it is simply stored inside the heart and belong to personal or group exclusively, without being translated into the reality of social life. In Islam, the concept of such a fundamental doctrine called 'Amar Ma'ruf' and 'nahi Munkar'; invoking to the virtue and preventing the 'munkar' based on the values of Islam. This concept also becomes the basis of the value framing into the communication practices of Islamic da' wah.

1-Ghozali in his book Ihya 'Ulumu al-Din wrote, indeed 'amar makruf nahi munkar' is the most important milestone of the great religions, and become the basis for the coming of the prophet. If the obligation of 'amar makruf nahi munkar' is ignored, its knowledge and its practice are neglected, then the prophetic would be futile, religion will be destroyed, confusion evenly, and finally the apostasy is contagious, the stupidity causes the damage and destruction widespread. Murtadha Muthahhari also stated, that the rise and fall of a society, especially Islamic society, the most important is determined by whether they practice the obligation 'amar ma'ruf nahi munkar' or not. When the Muslims left the practice of 'amar ma'ruf nahi munkar', then they will suffer the destruction or the downfall (Vahidi, 2011).

Basically, the practical form of the meant obligation is the attitude and behavior imbued by a sense of care for social problems (social concern). It is a soul which always willing to help each other in enforcing the goodness and the truth (amar ma'ruf), and prevent the damage (nahi munkar) sourced to the values of the Islamic religion, both in daily societal life and the life of people and the nation.

To make people would be willing to practice the virtues and avoid any munkar, first, it requires a systematic and sustained activity to plant and build solid personal and social concern at every value of ma'ruf and munkar. In Islam, the systematic and sustained efforts should be framed into a framework for the transformation process of the Islamic moral values. The purpose of the transformation process intended is to form a worldview (worldview) in every Muslim's mind and reason (state of mind) centered towards awareness, attitudes, and behavior based on the values of Islam in the midst of societal life.

History has recorded that Islamic da'wah implemented by the early generation of Muslims, is a monumental example from the transformation process of very impressive value. It reached social, political, economic, cultural areas and the systems of Muslim societies' belief (Ilyas: 2004).

Da'wah activity as a transformation process of the Islamic values should be able to form a sensitive soul to various social problems (sense of social problem) which hit the society; the social problems meant include the structural inequalities including the areas of social, economic, or political life, affecting the occurrence of poverty, injustice, arbitrary behavior, and other similar occurrences. Hence, the da' wah communication activity should not be only able to form individual piety (personal piety) but also social concern (social piety) in the religious practices. 
Nowadays, many da'wah activities utilize various media to convey the message of Islam. However, according to Ahmad Sobary, da'wah message delivered just on the outer skin of the Islamic precepts, furthermore, the traits are very partial and artificial. The implementation of da'wah communication has not practiced communication management based on facts, data, and targets. Meanwhile, the materials still rest on the issues of worship emphasizing the individual practice. The result is only up to the level of individual piety, which is built up, and has not been able to build social concern, namely a soul filled with the spirit to do good deeds for the society as a form of worship to God (Sobary, 2007)

Even in the case of Indonesia, the number of the worship place built in various towns and villages does not reduce various munkar occurred in social, cultural, economic, and political life. Such circumstances apply from the local, regional and national levels. The facts obtained by Yonky Karman proved that poverty, stupidity, and corruption, and other forms of lawlessness occurred (in Indonesia), are not decreased by the increasing of the worship places and religious rituals (Karman, 2007).

\subsection{Muhammadiyah and MTA among the Reality of Surakarta Society}

According to Poesponegoro's and Notosusanto's notes (1993), that entering the early $20^{\text {th }}$ century, Surakarta was developed into the most dynamic city in Java. In this city, there were a number of Dutch and Chinese companies, as well as natives' companies, especially batik business. In this city, the oldest native newspaper in Indonesia, Akbar Bromartani, was published in 1855. This newspaper was published weekly every Thursday, deliberately aimed for the natives, especially Javanese, by presenting the reality of social, economic, and political life at the time. Moreover, at that time, Muslims in Surakarta also began to raise their awareness to make a resistance against the arbitrary Dutch colonizers.

In 1905, The Unity of Islamic Trade (SDI) was established by Haji Samanhudi, a leading batik entrepreneur in this city. Islamic-based organization was originally intended to collect the Muslim traders to face Chinese traders who were given monopoly rights of batik materials by the Dutch colonial government. SDI in 1912 changed its name to the Islamic Unity (SI) and developed into a political movement organization based on the Islamic percepts, with the purpose of opposing the Dutch colonial government. SI continued to expand by opening the branches in several cities in Java. Meanwhile, the central movement moved into Surabaya, while in Surakarta since 1913 became one of SI branches (Ali, 2012).

The main character of SI Surakarta at that time was Haji Misbach known to be very brave in opposing against injustice and fighting for the poor and oppressed people. He was one of the initiators (ideologues) from the Indonesian Islam socialism in the early national movement in Indonesia. Before entering the SI, he was 'mubaligh' and the chairman of da'wah organization called SATV (Sidiq Amanah Tabligh Vatonah) established in 1917. SATV was the origin of the Surakarta Muhammadiyah organization (Prastyawati, 2007; Mu'arif, 2012; Ali, 2012). On January 25, 1922, SATV was renamed into Surakarta Muhammadiyah Branch (Amir, 2011).

According to Munir Mulkan's notes (2012) Muhammadiyah was established in Yogyakarta by KH. Ahmad Dahlan in 1912. At that time, the natives' life was very concerned. They were backward in economy, politics, education, and health. All of them were the result of the arbitrary Dutch colonial policy. Viewing such a reality, KH Ahmad Dahlan was compelled to take part as an effort to unravel the problems. His actions were based on the Qur'an Surah Alma'un. This surah contains the command for all Muslims to sympathize the poor and the orphans. If this is not implemented, then he is in a state of calamity, despite that Muslim is diligent to prayer daily. Based on the command of the verse, then since the beginning, Muhammadiyah beside practicing da'wah conventionally, also establishing the orphanages, educational institutions, and health clinics for the general society.

On September 19, 1972, the MTA (Quran Tafseer Council) was established in Surakarta by Ustad H. Abdullah Tufail Saputra. There are similarities with Muhammadiyah, the formation of this organization was constituted by Abdullah Tufail's concerns about the condition of Muslims who were backward socially, economically, and politically by the New Order, although politically Muslims have enormous contribution in establishing the New Order regime. The marginalization of Muslims according to him is about Muslims' religious understanding and practices deviated from the truly Islamic percepts.

Therefore, the MTA offers a deepening understanding of the sources of Islam, namely the Quran and Hadith. Abdullah Tufail was convinced that only by studying the Quran and Hadith, Muslims can understand and practice Islam in their daily life truly, concretely, have marwah (dignity), and able to be subject, not only as the object of others' willingness. Nowadays, the MTA has grown with 13 representatives with over 90 branches spread across the former residency of Surakarta, Jakarta, Surabaya, Medan and Bali. 


\subsection{Da'wah Communication and Social Concern}

If da'wah is presumed as a movement of social change and empowerment, then da'wah is a system of very important movement in the history of Islamic civilization. Da'wah can be seen as the facility or activator for the process of directed and planned social change with the aim of forming individuals, families, and societies as well as the world civilization blessed by God (Elias, 2010).

As a movement for change, conceptually da'wah activity has two definitions, namely a) the process of delivering a message containing the Islamic percepts and b) inviting people into a process toward the improvement of the life quality to be better. Basically, both of them are inviting or influencing mind by resuscitating, directing, and guiding people to behave in accordance with the universal truth of the values derived from Islamic percepts (Sobur, 2006). This means that da'wah is a communication process transforming the values of the Islamic percepts in order to build a worldview in every human being.

Worldview is one important aspect of human awareness. One's worldview is a mixture of beliefs, assumptions, attitudes, and ideas, which form an understanding model of each reality. Through a worldview, we can formulate a conceptual framework as a place of the growth of faith, which resuscitates about who we are and how the world in which we live. Therefore, one's worldview to the faced reality will determine the level of social awareness (social consciousness). Worldview and social concern are the two things, which become the basis for a person in doing self-identity and social identity (Schlitz and Miller, 2010).

The realization of religious concept is the birth of consciousness toward the highest social values. According to him, the form of consciousness meant is appreciate, being active, and uphold the highest social values. In Ames' view, religion should be placed as a source of the highest moral and social values in modern society. When religion becomes a source of the highest morals, the religious values will be the choice of the identity on every adherent's consciousness. Placing the faith in a higher social consciousness will produce a new perspective about the meaning of God and the reality of life.

Based on the statement written above, it can be made the formulation of social consciousness, a condition in which a person becomes aware of, understand, and feel the existence of a reality faced by society. In the measure of applied morals and norms, there are deviations or problems such as the difficulty of obtaining public resources, suffering, injustice, marginalization (marginalizing), and other similar conditions. In facts, he felt responsible for the social issues, until presumed himself to act to take part in order to find a way out of these problems, both individually and with others. This understanding is what researcher meant by the terminology of social concern.

The definition above is in line with Greene and Kamimura (2003) that social consciousness is one of the key elements for realizing social action. According to them, social consciousness is the power of booster inside a person to dare to: a) be firm against social injustice, b) raise societal consciousness on the environment, c) encourage tolerance and mutual respect for the differences related to race or religion; d) only use the goods produced by factories which hold strong ethics.

Someone who has a high social consciousness is the one who has been able to come out of the shell and come into the personality, which is spirited and behaved to prefer to concern others (selfless). Therefore, their souls become calm and feel useful when they can help others or society out of problems. Unlike people who have selfishness (Selfness), they must have low social consciousness.

Back to the discussion about the relationship between religious values and social consciousness, it is proven in Western society known with a secular ideology though, religious values are still an important factor, when interpreting social reality as well as in determining attitudes toward social issues they face in today's postmodern era. Therefore, mainly when they will take part in solving social problems requiring voluntary activity (voluntarily), they prefer to join a religious organization rather than other institutions. Nisbet and colleagues (2003) found that although American society's belief toward public companies, especially royal institutions continued to decline since the $1950 \mathrm{~s}$, but their support for religious activity remains high. Consistently, their belief in religious organizations and religious leaders were higher than the courts, congress, banking, public education, mass media, or the company.

Even religious organization is the most preferred place by Americans to join as a volunteer. Being a volunteer is a form of social concern, which has very high value, because they must sacrifice the possessions, mind, and soul for the sake of others who are suffering due to various reasons. People's activity belonging to the group of volunteers who are affiliated to religious organizations is a form of the most dominant social concern (Wuthenow, 1999) 
On another occasion, Gilbert (1993) and Jelen (1992) also found that the association of church networks is a combined form of groups and individuals to bind themselves. The networking activity of this church organization can influence and build their members' worldview and social behavior. Within this network, social and political issues also gain significant attention, in which the church opinion on that matter becomes the main reference. The decision of the church as well as proposed ideas that come from the churches they belong to involving the issue of society and public interest is delivered through a network of communication between them. Here, the group serves as a reference for the attitudes and behavior of its members.

What has been described above, it gives an idea about the existence of a positive relationship between religious beliefs and social consciousness and social concern. However, on the other hand, there are research findings, which prove the contrary, namely the higher the involvement in religious activity is, the higher the understanding and belief in religion are. However, it is precisely negatively associated with the increase of social concern. Nisbet and colleagues (2003) had tested these relations by placing some religious behaviors as independent variables and social capital namely the social and political beliefs as the dependent variables. Religious behavior tested by Nisbet includes three dimensions. They are a) the frequency of the attendance to the church and the involvement in the networking organization of the church as religion's associational dimension, b) the level of understanding toward the scriptures (Bible) as a religion's cognitive dimension; c) the membership to organizations, groups or particular religious beliefs as the dimension of sectarian affiliation (denominational affiliation). Once again, Nisbet and colleagues concluded that the three dimensions, both separately and together, are negatively related to social trust, social participation and political participation.

The evangelical of Protestant church, which is assumed to have a high level of religiosity, does not have the consciousness to the existing social reality. They tend to be conservative and doctrinal in behaved and prioritize the services for the group (Putnam, 2000; Greenberg, 2000; and Uslaner, 2000). More than that, Allport and Ross (in Nisbet and colleagues, 2003) revealed that those who have strong religious beliefs precisely have a low tolerance towards other individuals or groups. Moreover, that attitude is consistently held. The results of the study by Nisbet et al (2003) and Scheufele (2003) also found that such attitudes could occur due to the perspective developed in the activities of religious institutions is in-group-oriented perspective, not the perspective of togetherness. Therefore, they also tend to support only the existence of the group (reference group), rather than participate outside the group.

\section{Methodology}

The purpose of this study is to determine the relationship of the effects between the frequencies of receiving the Dash of Da'wah Communications Message (X1) as the independent variable toward the Behavior of Social Concern (Y) as the dependent variable. Because the effects of da'wah communication as well as behavior of social concern are very likely also influenced by other factors, so in the test of the relations, the three moderator variables are included, the frequency of Forwarding Da'wah Message Interpersonally (X2), the frequency of Using Mass Media (X3), and the Dependence to Reference Group (X4).

\subsection{Methods, population, and sample}

The applied method is survey with the object of the study is the participants of da'wah activities (Recitation= local terminology) held by a da'wah organization of Persyarikatan Muhammadiyah and Qur'an Tafsir Council (MTA), in the former residency of Surakarta. Administratively, this region has six districts, they are Surakarta called city, and four districts called counties consist of Sragen, Sukoharjo, Karanganyar, Wonogiri, Klaten, and Boyolali.

For the purpose of this investigation, the existing four districts out of 6 were taken, namely Surakarta (in local language also called Solo), Sragen, Sukoharjo, and Karanganyar. Those 4 districts were defined based on the consideration that Surakarta is the center of social, political, economic and cultural activities for the whole regions in the former residency of Surakarta. Meanwhile, three other districts are the areas directly bordered to the city of Surakarta. The three districts become a satellite of Surakarta.

Under the district, there is sub-district. Sub-districts chosen as the location of the study is the sub-district, which has the branch or representative of Muhammadiyah and the MTA, and actively conducting da'wah (recitation) sustainably. Therefore, there are 14 sub-districts, with the population of 1731 people consisting of Muhammadiyah is 1085 people and MTA is 646 people. Meanwhile, the number of sample was 414 people, divided into 260 people from Muhammadiyah and 154 people from the MTA. The number of sample units were assigned by using the stratified area proportional random sampling method. 


\subsection{Data collection, reliability, and validity}

Data was collected using a questionnaire instrument, in which the answers of each question item given the range scale of 1 to 5 , based on the Likert scale models. As mentioned earlier that this investigation involves 5 variables, divided into 2 main variables (X1 and $\mathrm{Y}$ ) and 3 moderator variables (X2, X3, and X4):

1. The frequency of receiving da'wah communication message (X1) measured by: a) the frequency of receiving the dash of da'wah messages directly, b) through the print media, b) electronic, and c) the level of da'wah message understanding.

2. The level of social concern $(Y)$ is the action to take part in solving various social problems occurred in society, as measured through the following activities: a) engaged in social organization, b) control the social order in society; c) the charity for social purposes; d) volunteer for social work or the empowerment of the weak people; e) dividing the recommendation to solve the social problems

3. The frequency of forwarding da'wah message interpersonally (X2) measured by: the frequency of forwarding da'wah message which has been received to a) friend b) neighbors, c) family members; d) the public society, and e) as the place to argue about religious percepts.

4. The role of the reference group $(X 3)$ is the degree of respondents' dependence to the group of recitation accompanied as a reference to determine the attitudes and behaviors. They include: a). feeling of being part of a group, b) feeling proud as a member of the group, c) assessing the group better than others, and d) often wishing to recommended the group to be acted and behaved.

5. The frequency of using mass media is the frequency of searching or conveying information beside religion through the mass media through: a) radio, b) television c) the print media, and d) the Internet.

To determine the reliability of the instrument, the study used Cronbach's Alpha test with significant price 0.6. If the coefficient of test result is greater than 0.6 , then the instrument of the study is reliable

Table 1: The Reliability of Data Instrument

\begin{tabular}{lll}
\hline Variables & The number of item & C. Alpha \\
\hline The dash of da'wah message & 7 & 0.678 \\
Interpersonal sustainability & 6 & 0.768 \\
Using mass media & 4 & 0.741 \\
Reference group & 11 & 0.601 \\
Political participation & 12 & 0.701 \\
\hline
\end{tabular}

\section{Discussion and Conclusion}

Due to the relations of the influence involve a moderator variable the method used to test is Moderated Regression Analysis (MRA). The provision for the application of this method starts with a simple regression test over the main variable and must be significant at the 5\% alpha. If the coefficient of regression test result is significant, then the test MRA can be continued, but if not MRA cannot be continued. The following table shows the simple regression test results for direct relations between the levels of the Acceptance Da'wah Dash (X1) to the level of social concern (Y).

Table 2: The Direct Influence between X1 toward Y

\begin{tabular}{lllclcl}
\hline Model & $\begin{array}{l}\text { Sum } \\
\text { Squares }\end{array}$ & of df & $\begin{array}{l}\text { Mean } \\
\text { Square }\end{array}$ & F & Sig. \\
\hline 1 & Regression & 4.321 & 1 & 4.321 & 19.080 & $.000^{\mathrm{B}}$ \\
& Residual & 93.313 & 412 & .226 & & \\
& Total & 97.634 & 413 & & & \\
\end{tabular}

a. Dependent Variable: Social Concern (Y)

b. Predictors: (Constant), The Dash of Da'wah (X1)

The table above provides an explanation that there is a real influence between the Frequency of Receiving Da'wah Message Dash (X1) toward the behavior of social concern (Y). Essentially, the value of F-test obtained 19.080 greater than the $\mathrm{F}$ table $(19.080>3.86)$ and significant value is smaller than the Alpha $5 \%(0,00<0,50)$. 
In other words, the more often a person receives a da'wah message or involves in da'wah communication activities, the higher level of social concern is. Later, based on the information above, the MRA correlation test can be continued.

MRA model serves to determine the function of moderator variables in the relation of the influence between independent variables and the dependent variables. The one, which wants to be known through this MRA test are: 1) how big the role or influence of each independent variable (X1) and X1 interaction with the moderator variable separately toward the dependent variable. It can be seen at the amount of the value t-test resulted, 2) the effect of the independent variable (X1) and X1 interaction with moderator variable together (simultaneously) towards dependent variable. For the second, it can be proven based on the results of the F-test.

The table 3 shows the amount of the coefficient t-test from the interaction between the independent variable and the moderator variable toward dependent variable, which is social concern.

Table 3: The Result of $t$-test

\begin{tabular}{lllll}
\hline $\begin{array}{l}\text { Independent } \\
\text { Variable }\end{array}$ & Dependent Variable & t-test & Significance & Description \\
\hline$X 1$ & & -2.03 & 0.043 & Influenced \\
$X 1(X 2)$ & Social Concern $(Y)$ & 2.29 & 0.022 & Influenced \\
$X 1(X 3)$ & & 4.57 & 0.000 & Influenced \\
$X 1(X 4)$ & & 2.40 & 0.017 & Influenced \\
\hline
\end{tabular}

The Value of t-test for the variable of Da'wah Message Dash (X1) is -2.03 is smaller than t table $(-2.03<1.966)$ and a significant value of 0.043 is smaller than alpha $5 \%(0.043<0.050)$. It can be stated that although the influence of Da'wah Message Dash (X1) toward the Social Concern (Y) is significant, but the influence is very weak.

Furthermore, the t-test for the interaction between the variable of Da'wah Message Dash and the variable of Forwarding Da'wah Message Interpersonally [X1 (X2)] is 2.29 and significant value 0.022 . Since the value of ttest is greater than $t$ table $(2.29>1,966)$ or significant value is smaller than alpha $5 \%(0.022<0.050)$, it can be stated that the moderator variable of Forwarding Da'wah Message Interpersonally (X2) has a role to reinforce the influence of Da'wah message Dash (X1) toward the Behavior of Social Concern (Y) at the significant level of $5 \%$.

T-test value for the interaction between the variables of Da'wah Message Dash and moderator variable of the Role of Reference Group [X1 (X3)] is 4.57 and significant value of 0.00 . Since the value of t-test is greater than $\mathrm{t}$ table $(4.57>1,966)$ or significant value is smaller than alpha $5 \%(0.000<0.050)$, it can be concluded that the Role of Reference Group (X3) has the function of reinforcing the influence of Da'wah Message Dash toward the Behavior of Social Concern (Y) at the significant level of $5 \%$.

T-test value for the interaction between the variable of Da'wah Message Dash and moderator variable of the Frequency of Using Mass Media [X1 (X4)] at 2.40 is greater than the theoretical t $(2.40>1,966)$, and the significant value is 0.017 is greater than alpha $5 \%(0.017>0.050)$. It can be stated that the moderator variable of the Frequency of Using Mass Media serves to reinforce the influence of Da'wah Message Dash toward the Behavior of Social Concern at significant level of $5 \%$.

Based on the comparison of the t-test value above, it can also be seen that the frequency of conveying or forwarding the da'wah message interpersonally (X3) and the dependence on the reference group (X4) has the greatest role to reinforce the influence of da'wah message dash (X1) toward the level of behavior of social concern ( Y).

Furthermore, it will be described the influence of the independent variable (X1) and X1 interaction with moderator variable simultaneously (together) toward the dependent variable. 
Table 4: The Result of F-test for Social Concern (Y)

\begin{tabular}{lllll}
\hline $\begin{array}{l}\text { Independent } \\
\text { Variable }\end{array}$ & Dependent Variable & F-test & Significance & Description \\
\hline$X 1$ & & & & \\
$X 1(X 2)$ & Social Concern $(Y)$ & 13.799 & 0.000 & Influenced \\
$X 1(X 3)$ & & & \\
$X 1(X 4)$ & & & \\
\hline
\end{tabular}

Based on the table above, the value of F-test was found at 10.004 and the significant value at 0.000 . The value of $\mathrm{F}$ table in $\mathrm{db}_{1}=4$ and $\mathrm{db}_{2}=408$ and Alpha 5\% is amounted to 2.394. Evidently, F-test value produced is greater than the value of $\mathrm{F}$ table $(13.799>2,394)$, and a significant value is smaller than alpha $5 \%(0.000<0.050)$. Therefore, it can be concluded that the variables of Da'wah Message Dash (X1) and X1 interaction with the moderator variable of Interpersonal Submission [X (X2)], the Role of Reference Group [X (X3)], and the Frequency of Using Mass Media [X1 (X4)], simultaneously affects the variable of the Behavior of Social Concern (Y) with the level of mistakes at $5 \%$.

Meanwhile, to explain the enormous mutual influence can be based on the enormity of determinant square value $\left(\mathrm{R}^{2}\right)$ shown in the table below.

Table 5: Determinant Value $\left(\boldsymbol{R}^{2}\right)$

\begin{tabular}{lllll}
\hline & \multicolumn{3}{c}{ Model Summary $^{\mathbf{b}}$} \\
\hline Model & $\mathrm{R}$ & $\mathrm{R}$ Square & Adjusted R Square & Std. Error of the Estimate \\
1 & $.349^{\mathrm{A}}$ & .119 & .111 & .45802 \\
\hline a. Predictors: (Constant), X1 (X4), X1 (X3), X1 (X2), X1 \\
b. Dependent Variable: Y
\end{tabular}

Coefficient $\mathrm{R}^{2}$ value obtained is amounted to 0.119 , then the enormity of the simultaneous effect as mentioned above is amounted to 0.119 , or approximately $11,9 \%$, and the remaining $88.1 \%$ is influenced by other factors outside of the variables studied.

The following discussion is about the form of the relations of the influence from the independent variable and the moderator variable toward dependent variable. This form of the relation of the influence meant is the form of positive or negative relations. For these needs, it can be seen in the coefficient of the results of the moderated regression analysis (MRA), as shown in Table 6.

Table 6: The Coefficient of Moderated Regression Analysis (MRA)

\begin{tabular}{|c|c|c|c|c|c|}
\hline \multicolumn{6}{|c|}{ Coefficients $^{\mathrm{a}}$} \\
\hline \multirow[t]{2}{*}{ Model } & \multicolumn{2}{|c|}{$\begin{array}{l}\text { Unstandardized } \\
\text { Coefficients }\end{array}$} & Standardized Coefficients & $\mathbf{t}$ & Sig. \\
\hline & $\mathrm{B}$ & Std. Error & Beta & & \\
\hline 1 (Constant) & 2.207 & .226 & & 9.745 & .000 \\
\hline $\mathrm{X} 1$ & -.240 & .118 & .163 & -2.031 & .043 \\
\hline $\mathrm{X} 1(\mathrm{X} 2)$ & .029 & .012 & .135 & 2.293 & .022 \\
\hline X1 (X3) & .071 & .015 & .315 & 4.576 & .000 \\
\hline $\mathrm{X} 1(\mathrm{X} 4)$ & .033 & .014 & .135 & 2.407 & .017 \\
\hline
\end{tabular}

a. Dependent Variable: The Behavior of Social Concern (Y)

Referring to the table above, the explanation can be obtained as follows:

1. The coefficient value of the variable of Da'wah Message Dash (X1) is amounted to 0.163 and is positive, stated that the higher the activity of Da'wah Message Dash is done, the more increased the influence of the behavior of social concern is.

2. The coefficient value of the variable of Da'wah Message Dash (X1) with the moderator variable of Forwarding Da'wah Message Interpersonally (X2) amounted to 0.135 and is positive, give the information 
that the more often a person forwards da'wah message interpersonally, the more increased/ stronger the influence of da'wah message dash toward the behavior of social concern is.

3. The Coefficient value of the variable of Da'wah Message Dash (X1) with the moderator variable of the Behavior of Depending on Reference Group (X3) amounted to 0.315 and is positive. The condition implies that Reference Group (X3) is contributed to reinforce the influence of Da'wah Message Dash toward the level of Social Concern.

4. The coefficient value of variable of Da'wah Message Dash (X1) with the moderator variable of the Frequency of Using Mass Media (X4) amounted 0.135 and is positive. It indicates that the more frequently respondents use the mass media the more increased the effect of da'wah message dash toward the behavior of social concern.

From the explanation above, it can be given the affirmation: a) that indeed the influence of da'wah message dash seems less real despite significant. This was proven through the t-test $=-2.031$ smaller than $\mathrm{t}$ table $=1.966$; though significant at alpha $5 \%(0.043<0.050)$, b) all the moderator variables serve to strengthen the influence of da'wah message dash toward the behavior of social concern, c) between three moderator variables tested, they are the Role of Reference Group (X3) which has the greatest role to reinforce the influence of da'wah message dash toward the level of social concern.

Referring to the 3 kinds of affirmation above, it can be concluded that the reality presented by the mass media has the greatest role to form the attitudes and behaviors of social concern. Therefore, the materials of da'wah communication can be packed more touching to the realities and the needs of the society. One way is to utilize the public issues presented by the mass media as a source of da'wah messages. In other words, the contents of da'wah message should not be only textual but also must be contextual to the social, cultural, economic, political realities developed in society. In this way, da'wah activity could give the answer on the problems experienced by the society and not just be "black and white and in the clouds".

\section{References}

Ali, Muhammad, (2012), SATV, Cikal Bakal Muhammadiyah Surakarta (Catatan Tambahan untuk Muarif), http://muhammadiyahstudies. blogspot.com

Amir, Muhammad, (2011), Sejarah Masuk dan Berkembangnya Muham-madiyah di Surakarta, http://muhammadiyahstudies.blogspot.com/

Gilbert, CP (1993) The Impact of Churches on Political Behavior: An Empirical Study, Westport, CT: Greenwood.

Greenberg, A., (2000), The Church and revitalization of Poltics and Community, Political Science Quarterly, Volume 115.

Ilyas, H. Yunahar (2004) Globalisasi danTantangan Dakwah, 'Ulumuddin Digital Journal Al-Manar, Edisi I/2004

Ilyas, M.(2010). Komunikasi Dakwah, kertas kerja pada Pelatihan Kader mubalig PUI Jawa Barat, Indonesia, 2831 Januari 2010

Jelen, TG, (1992). Political Christianity: A Contextual Analysis, American Journal of Political Science, Volume 36.

Karman, Yonky., (2007). Robohnya Kepedulian sosial, Akbar Harian Kompas, Opini, 14 Juni 2007.

Muarif, (2012). Perkumpulan Pra Muhammadiyah di Surakarta, Majalah Suara Muhammadiyah, No 14-16/Th ke-95.

Nisbet, Matthew C., Moy, Patricia., \& Schenfele, Dietram A., (2003), Religion, Communication, and Social Capital. Paper presented at the Annual Meeting of the International Communication Association, Mariot Hotel, San Diego, CA, 27 Mei 2003. http://www.allacademic.com

Poesponegoro, Marwari, Djoened., \& Notosusanto, Nugroho, (1993)., Sejarah Nasional Indonesia $V$, Departemen Pendidikan dan Kebudayaan Republik Indonesia: Jakarta.

Prastyawati, Rossyita Diah, (2007). Partai Masyumi Cabang Surakarta Pada Tahun 1954-1960. Skripsi Sarjana Sejarah, Fakultas Sastra dan Seni Rupa, Universitas Sebelas Maret, Surakarta.

Scheufele, DA, Nisbet, MC, and Brossard, D., (2003), Pathway to Political Participation? Religion, Communication Contexts, and Mass Media, International Journal of Public Opinion Research, Volume 15, No. 3 .

Schlitz, MM, Vieten, C., \& Miller, EM, (2010). Worldview Transformation and Development of Social Consciousness, Journal of Consciousness Studies, Volume 17, No. 7-8. 
Sobur, HA Kadir, (2006), Inovasi Mekanisme Dakwah: Suatu Analisis Berdasarkan Filsafat Qur'ani, Jurnal Inovatio, Volume 5, No. 10, Juli-Desember 2006.

Uslaner, EC, (2000), Producing and Consuming Trust, Political Science Quarterly, Volume 115.

Vahidi, Hamzeh Ali., (2011), Pemikiran Muthahari dan Muhammad Abduh; Sebuah Telaah Komparatif, Lembaga Pendekatan Mazab-Mazab Islam, (11/1/2011, 23:30 pm)

Wuthenow, R., (1999), Mobilizing Civic Engagement: The Changing Impact of Religious Involvement, Dalam: T. Skocpol and MP Fiorina (Eds), Civic Management in American Democracy, Washington, DC: Brookings / Russell Sage 